\title{
2.5 Mesenchymal Stem Cell Therapy has significant clinical effect in proteoglycan induced arthritis JF Swart*2, MJG Backer ${ }^{3}$, F Hofhuis ${ }^{3}$, W de Jager1, BJ Prakken11, W Kuis'1, ACM Martens ${ }^{3}$ and NM Wulffraat ${ }^{1}$
}

\author{
Address: ${ }^{1}$ Department of Pediatric Immunology, Wilhelmina Children's Hospital/UMC Utrecht, Utrecht, Netherlands, ${ }^{2}$ VU University Medical \\ Center, Amsterdam, Netherlands and ${ }^{3}$ Department of Immunology, UMC Utrecht, Utrecht, Netherlands \\ * Corresponding author
}

\author{
from 15th Paediatric Rheumatology European Society (PreS) Congress \\ London, UK. 14-17 September 2008 \\ Published: 15 September 2008 \\ Pediatric Rheumatology 2008, 6(SuppI I):S5 doi:10.1 186/I546-0096-6-SI-S5
}

This abstract is available from: http://www.ped-rheum.com/content/6/SI/S5

(c) 2008 Swart et al; licensee BioMed Central Ltd.

\section{Introduction}

Mesenchymal Stem Cells (MSC) are adult stem cells which are mainly present in bone marrow and fat. The cell is a fine candidate for treatment of juvenile idiopathic arthritis since it has strong immunosuppressive activities in vitro as well as in vivo $[1,2]$.

\section{Methods}

We performed a study with $104 \mathrm{Balb} / \mathrm{c}$ mice with 55 as donors of MSC. The 49 mice that were induced twice with human proteoglycan for the development of PGIA were randomly assigned to 5 groups: 1 control-group (PBS) and 4 treatment-groups (MSC once or twice intraperitoneal [ip] or intra-articular [ia]). Ten days after $2^{\text {nd }}$ PG-antigen injection, treatment was started and if planned again after 4 weeks. Dosages were $5 \times 10^{6}$ ip and $1 \times 10^{6}$ cells ia. MSC used were syngeneic and passaged twice. Arthritis was scored 2 times a week by 2 independent observers according to a scoringsystem with a maximum of 16 .

\section{Results}

Arthritis-score was on average $1.3(0.8-2.0)$ just before start of the treatment and increased to 6.0 in the control group towards the end of the experiment (day 67). At day 67 arthritis-scores were significantly lower in both ipgroups (1.0 and 0.5) and in the repeated ia-group (2.0). Furthermore in both ip-groups arthritis-scores decreased after treatment and stabilized until day 67 .

\section{Conclusion}

High dose MSC systemically administered (ip) has good clinical effect on established arthritis. Arthritisscore not only stabilized but even diminished after injection of ip MSC. Ip injection of MSC once was as good as twice; this was not true for the ia injection.

\section{References \\ I. Uccelli A, et al.: Eur J Imm 2006. \\ 2. Le Blanc K, et al.: Lancet 2004.}

